\title{
MECHANICAL PROPERTIES OF WOOD-GEOPOLYMER COMPOSITE
}

\author{
Andris Berzins ${ }^{1}$, Andris Morozovs ${ }^{1}$, Uldis Gross ${ }^{1}$, Janis Iejavs ${ }^{2}$ \\ ${ }^{1}$ Latvia University of Agriculture, ${ }^{2}$ Forest and Wood Products Research and Development Institute, \\ Latvia \\ andriz.berzins@gmail.com, andris.morozovs@1lu.lv, uldis.gross@1lu.lv, janis.iejavs@e-koks.lv
}

\begin{abstract}
In recent years the popularity of ecological and renewable materials has grown. Aware of the limited resources as well as availability of local resources and economic grounds, the attention is paid to the development of new materials. Currently, there is a political as well as a societal demand for products that require less energy for the manufacturing process and are easy to recycle with less impact on environment. In comparison with concrete, wood-geopolymer emits less $\mathrm{CO}_{2}$, it is environmentally friendly and made from available local resources. Therefore, the geopolymer composites obtained from clay, sodium silicate and wood particles or fiber could be one of the solutions. Geopolymers are inorganic polymers that are formed by the polymerization reaction of silico-aluminate and silico-oxide. In this case, the geopolymer is formed from clay, which is mined in Latvia (silico-aluminate) and water glass (silico-oxide). The wood-geopolymer was made by mixing geopolymer with softwood particles. The aim of the research was to develop a wood-geopolymer composite material and to evaluate its optimal composition and properties. The study defined the impact of the compound on the mechanical and physical properties (bending strength, compressive strength, modulus of elasticity, swelling and thermal conductivity) of the wood-geopolymer composite. The current paper presents mechanical properties of different composition and treatment methods of wood-geopolymer. As a part of the research the geopolymer and wood geopolymer thermal conductivity was compared. The results have shown that there is a correlation between the wood-geopolymer density and the thermal conductivity. The same correlation was observed between the wood-geopolymer density and the mechanical strength.
\end{abstract}

Keywords: geopolymer; wood; sodium silicate; clay; mechanical properties

\section{Introduction}

The wood treatment process promotes the formation of a by-product - sawdust, which in Latvia is mainly used for production of bioenergy, however, this type of usage does not ensure the highest possible added value. Wood chips can also be combined with inorganic materials, thus obtaining composite materials with unique properties [1]. Inorganic composite materials can be obtained by mixing wood together with inorganic material in the aquatic environment, allowing the inorganic matrix to become stiff and make a durable composite. Some of the inorganic composite materials are highly resistant to formation of fungus, insects and pests. Most of them have a high fire resistance [2].

The wood-geopolymer composite material consists of two components - wood and geopolymer. Depending on the wood and geopolymer ratio in the material, the properties of the wood-geopolymer composite material vary. The main functions of wood in the composite material are weight reduction, reduction of thermal conductivity [3;4] and the fixture function [5]. Whereas the main functions of geopolymer are bonding of wood particles, improvement of fire resistance [6; 7], providing mechanical strength [8], improvement of humidity resistance and protection against fungal and insect damages [4].

The wood-geopolymer composite material in the building walls can serve as a microclimate regulator absorbing the moisture when the air humidity is high and returning the moisture when there is a low air humidity period, thus improving the hygrothermal comfort in the building [9].

Geopolymer has not only excellent mechanical properties, but it ensures also significant reduction of $\mathrm{CO}_{2}$ emissions compared to concrete [10]. Geopolymers are amorphous three-dimensional alkali aluminosilicate materials, which have been developed as an environmentally friendly alternative to cement, as their production is not connected with limestone calcination. The need for an environmentally friendly building material is an important issue in order to maintain sustainable environmental development [4]. Geopolymer materials contain aluminum ( $\mathrm{Al}$ ) and silicon ( $\mathrm{Si}$ ) compounds soluble in strong alkali solutions. Any material that is rich in $\mathrm{Al}$ and $\mathrm{Si}$ in amorphous form may be the potential raw material for geopolymer [11].

Quantity of Si-Al material involved in polycondensation depends on the particle size, the Al-Si material solubility and concentration $[4 ; 12]$. The formation of geopolymer is influenced by the heat treatment of raw materials - calcined materials such as slag, fine ash and metakaolin, which mostly are 
in amorphous form, usually show a better reactivity compared with non-heated materials [13; 14]. Raw materials are subjected to thermal treatment from 400 to $800{ }^{\circ} \mathrm{C}$ before using them [15].

Mostly in the geopolymerization process sodium silicate $\left(\mathrm{Na}_{2} \mathrm{SiO}_{3}\right)$ or potassium silicate $\left(\mathrm{K}_{2} \mathrm{SiO}_{3}\right)$ in combination with sodium hydroxide $(\mathrm{NaOH})$ or potassium hydroxide $(\mathrm{KOH})$ serve as alkali activators. It should be mentioned that they can be both in dry form and in solution; however, dissolving requires an appropriate environment $[8 ; 11]$.

Using of different alkali activators also changes the required concentration [8] and the desired dissolution environment. During the geopolymer synthesis water participates in dissolution, as well as in hydrolysis and polycondensation reactions. Water provides an environment for dissolution of aluminosilicates, movement of ions, hydrolysis of $\mathrm{Al}^{3+}$ and $\mathrm{Si}^{4+}$ compounds and polycondensation of various aluminum and silicon hydroxycompound groups. As a result, water has a great influence on the formation of geopolymer, geopolymer gel structure and product characteristics [16]. Although water is needed to ensure the environment, the excess of it can weaken the material. Excessive water contributes to the porosity of the material, which makes it too loose to use it for construction [4]. Reactivity of the raw material is affected by the particle size. A small particle size enhances dissolution and reduces the amount of unreacted particles [4].

Geopolymer, like concrete, reaches its maximum strength after a long period. A significant strength of geopolymer is gained already after 2 to 5 hours [13], however, the maximum strength is reached only after 28 days [17].

At present, research in geopolymers mainly is based on fine ash and different slag, however, Latvia is rich in clay resources, therefore this study is based on the resources that are local and also available. Using local raw materials in building construction, the impact on the environment, as well as the final price of the product are significantly reduced [9]. The study examines wood and geopolymer composite and determines its bending strength, modulus of elasticity, compressive strength, swelling and thermal conductivity.

\section{Materials and methods}

Materials: pine sawdust (Ltd. "Dendrolight Latvia") with dimensions of 0.2-0.25 x 2 to 3.5 x 0-25 $\mathrm{mm}$, specified particle humidity of $10 \pm 0.5 \%$. Clay powder Ltd. "Ceplis", clay obtained in Latvia, Auces region. From the clay powder was used fraction particles with a size $\leq 0.5 \mathrm{~mm}$. Clay powder was sieved with $0.5 \mathrm{~mm}$ sieves, then calcined at a temperature of $700{ }^{\circ} \mathrm{C}$ to obtain calcined clay. Sodium silicate solution (water glass), Ltd. "LEANA" product. The specified weight of sodium oxide in sodium silicate solution is $0.00135 \mathrm{~g} \mathrm{~mol}^{-1}$ and determined dry content is $0.47 \%$.

Equipment: Zwic mechanical strength testing equipment; Netzsch HFM 436 thermal conductivity detection device; Memmert GmbH thermostat with forced ventilation; Nabertherm GmbH muffle kiln; Joos-Labor-Presse LAP60 press, scales.

Composite sample preparation: according to the composition in Table 1, sodium silicate is mixed with water, then clay powder is added and mixed. Finally wood particles (sawdust) are added and the mixture is stirred for about $15 \mathrm{~min}$. When the mixture is finished, it is placed in a suitably sized form. Samples need additional pressure of $700 \mathrm{~N}$ force, after that they are left for appropriate time under $250 \mathrm{~N}$ weight. After pressing, the samples are wrapped in foil and kept in $75^{\circ} \mathrm{C}$. The samples are cooled, unwrapped from the foil and 28 days kept in $20 \pm 5^{\circ} \mathrm{C}$. For each quality test three parallel samples were prepared from each group. Afterwards samples are tested according to the testing method.

Table 1

Samples of wood-geopolymer composite

\begin{tabular}{|c|c|c|c|c|c|c|}
\hline Sample & $\begin{array}{c}\text { Calcined } \\
\text { clay, g }\end{array}$ & $\begin{array}{c}\text { Sodium } \\
\text { silicate } \\
\text { solution, }\end{array}$ & $\begin{array}{c}\text { Pine } \\
\text { sawdust, } \mathbf{g}\end{array}$ & $\mathbf{H}_{\mathbf{2}} \mathbf{O}, \mathbf{g}$ & $\begin{array}{c}\text { Heating } \\
\text { time, } \mathbf{h}\end{array}$ & $\begin{array}{c}\text { Pressing } \\
\text { time, } \mathbf{\text { min }}\end{array}$ \\
\hline L1 & 56.95 & 539.60 & 167.22 & 171.23 & 24 & 57 \\
\hline L2 & 75.43 & 528.24 & 163.70 & 167.63 & 24 & 57 \\
\hline L3 & 57.03 & 589.90 & 142.33 & 145.74 & 24 & 57 \\
\hline
\end{tabular}


Table 1 (continued)

\begin{tabular}{|c|c|c|c|c|c|c|}
\hline Sample & $\begin{array}{c}\text { Calcined } \\
\text { clay, g }\end{array}$ & $\begin{array}{c}\text { Sodium } \\
\text { silicate } \\
\text { solution, g }\end{array}$ & $\begin{array}{c}\text { Pine } \\
\text { sawdust, }\end{array}$ & $\mathbf{H}_{\mathbf{2}} \mathbf{O}, \mathbf{g}$ & $\begin{array}{c}\text { Heating } \\
\text { time, h }\end{array}$ & $\begin{array}{c}\text { Pressing } \\
\text { time, min }\end{array}$ \\
\hline L4 & 60.25 & 531.19 & 189.59 & 153.97 & 24 & 57 \\
\hline L5 & 59.68 & 526.18 & 158.65 & 190.49 & 24 & 57 \\
\hline L6 & 61.68 & 543.85 & 163.98 & 165.49 & 38 & 57 \\
\hline L7 & 61.68 & 543.85 & 163.98 & 165.49 & 26 & 80 \\
\hline
\end{tabular}

Determination of bending and elasticity modulus: before bending and compressive test samples are conditioned at $60 \%$ relative air humidity and at $23{ }^{\circ} \mathrm{C}$ according to standard. Bending and elasticity modulus sample dimensions are $290 \times 50 \times 14 \mathrm{~mm}$. With Zwic equipment the sample elasticity modulus and bending strength (three-point bending) is determined according to the standard LVS EN 310: 2001 [18]. Sample dimensions $290 \times 50$ x $14 \mathrm{~mm}$. The loading rate of $3 \mathrm{~mm} \cdot \mathrm{min}^{-1}$, the distance between supports $240 \mathrm{~mm}$.

Compressive strength: compression test samples are conditioned at $60 \%$ relative air humidity and $23{ }^{\circ} \mathrm{C}$ according to the standard. Compressive test sample size $50 \times 50 \times 35 \mathrm{~mm}$. Compressive strength is determined by the Zwick equipment. Pressing time is $90 \pm 15$ seconds.

Swelling determination: the sample size $50 \times 50 \times 12 \mathrm{~mm}$. At first, samples are incubated at room temperature $20 \pm 2{ }^{\circ} \mathrm{C}$, then the sample length, width and thickness is measured. Measurements are conducted with the electronic caliper at $0.01 \mathrm{~mm}$ accuracy. Measurement scheme is given in Figure 1.

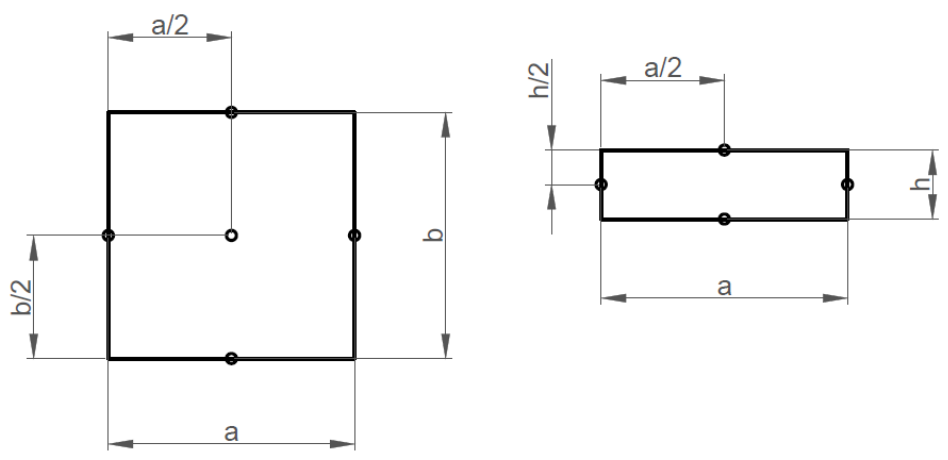

Fig. 1. Measurement scheme of swelling determination

After the measurement, the samples are dried at $103 \pm 2{ }^{\circ} \mathrm{C}$ and repetitive dimension measurements are performed. Afterwards samples are placed in water for 24 hours to completely swell. Repetitive dimension measurements are performed. The wood-geopolymer swelling is determined according to the equation (1).

$$
\delta l_{0 ; 100}=\frac{l_{100}-l_{0}}{l_{0}} \cdot 100
$$

where $\delta l_{0,100}$ - sample length / width / thickness changes followed by changes in woodgeopolymer composite humidity from $0 \%$ to $100 \%$;

$l_{0}$ - sample length / width / thickness after drying at $103^{\circ} \mathrm{C}$ temperature (absolutely dry sample);

$l_{100}$ - sample length / width / thickness after removal from water (absolutely swelled sample).

Determination of wood-geopolymer and geopolymer thermal conductivity coefficient: required sample size according to the testing is $290 \times 290 \mathrm{x} \leq 80 \mathrm{~mm}$. Mixture composition: calcined clay $20 \%$, sodium silicate solution $-44 \%$, wood particles $-18 \%$, water $-18 \%$. In the bowl prescribed for mixing the sodium silicate is mixed with calcined clay, stirred for $10 \mathrm{~min}$, then wood particles are added. Stirred until the mixture is thoroughly mixed evenly. Prepared mass is put in pressing form $(300 \times 300 \times 100 \mathrm{~mm})$, evenly smoothing and pressing it. The samples are pressed with $1 \mathrm{MPa}$ 
pressure, pressing time $1 \mathrm{~h}$. After removing the sample from the press form is wrapped in foil and placed for $24 \mathrm{~h}$ at $75^{\circ} \mathrm{C}$. The samples are cooled and left to harden for 28 days. When samples are solid, they are subjected for thickness calibration on wide belt grinding machines and the sides are grinded to obtain the required sample size. Three parallel samples are prepared.

Mixture composition for geopolymer thermal conductivity sample preparation: calcined clay $19.5 \%$, sodium silicate solution $-19.5 \%$, sand $-59 \%$ and water $-2 \%$. At first sodium silicate solution is mixed with water, then calcined clay and sand with fraction particle size of $\leq 2 \mathrm{~mm}$ is added. Mixture is stirred until homogenous (approximately $5 \mathrm{~min}$ ), then poured into forms, levelled, wrapped in foil and placed for $24 \mathrm{~h}$ at $75^{\circ} \mathrm{C}$. The samples are cooled and left to harden for 28 days. Three parallel samples are prepared.

The thermal conductivity coefficient is determined with Netzsch HFM 436 equipment using hot plate method.

\section{Results and discussion}

Mechanical properties of wood-geopolymer: the obtained bending strength parameters are given in Figure 2 (error bars showing standard deviation). The best bending strength was achieved by sample L3 - 1.5 MPa strength, similar strength was achieved by sample L5 - 1.47 MPa. Lowest result was achieved by L4 sample, only $0.97 \mathrm{MPa}$.

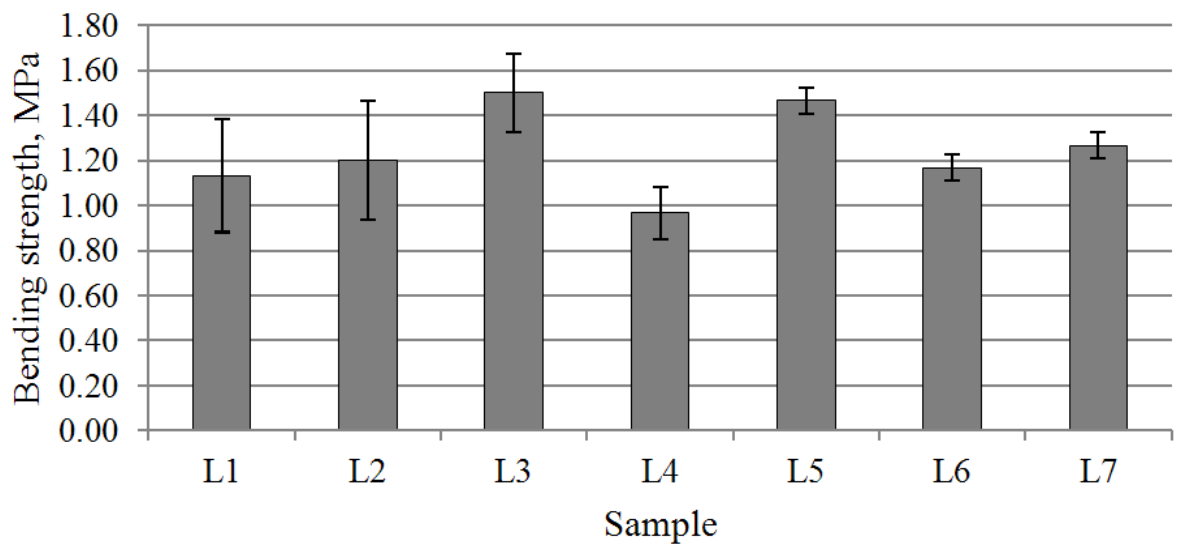

Fig. 2. Bending strength of wood-geopolymer

Similar situation could be observed with elasticity modulus. The best performance was recorded for L3 and L5 samples, respectively, $402 \mathrm{MPa}$ and $445 \mathrm{MPa}$. Similarly, lowest elasticity modulus was registered for L4 - only $265 \mathrm{MPa}$. Looking on composition characteristics (Table 1), it can be observed that in L3 case there is more liquid glass added, but in case of L5 - more water. Predominance of liquid ingredients moistens sawdust more thoroughly and allows to press it better. While in case of L4 there are more wood particles that work on the contrary. After elasticity modulus (Figure 3) it can be concluded that sodium silicate solution reduces elasticity, but increases strength.

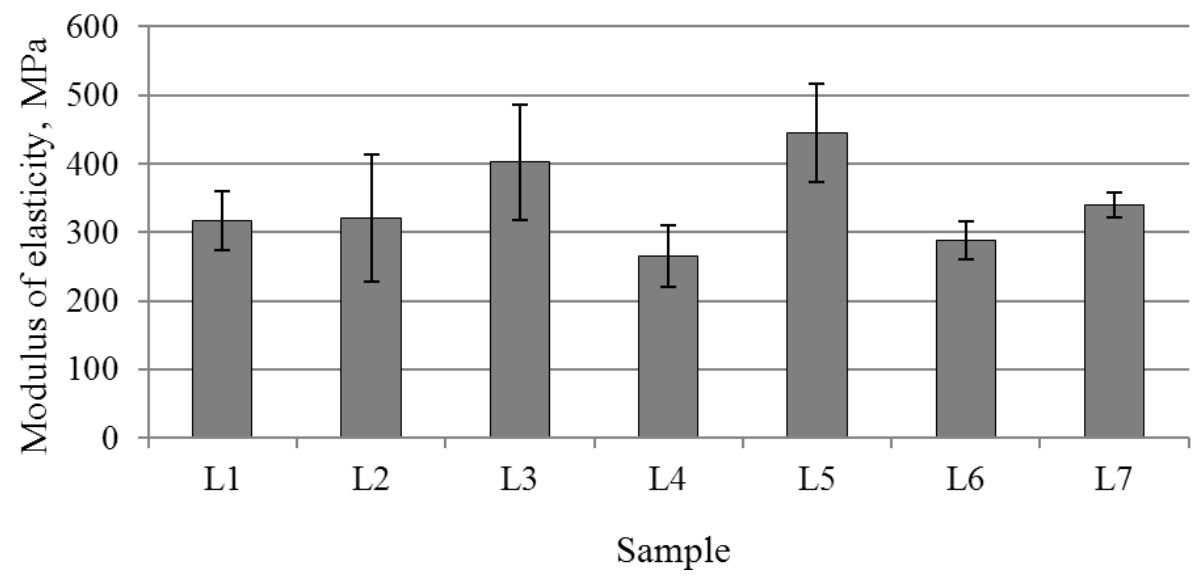

Fig. 3. Modulus of elasticity of wood-geopolymer 
The obtained compressive strength indicators (Figure 4) are not significantly different from the bending strength, only a slight difference appears between L6 and L7 samples. The bending strength and modulus of elasticity was higher for L7 sample, but higher compressive strength was observed for L6 sample.

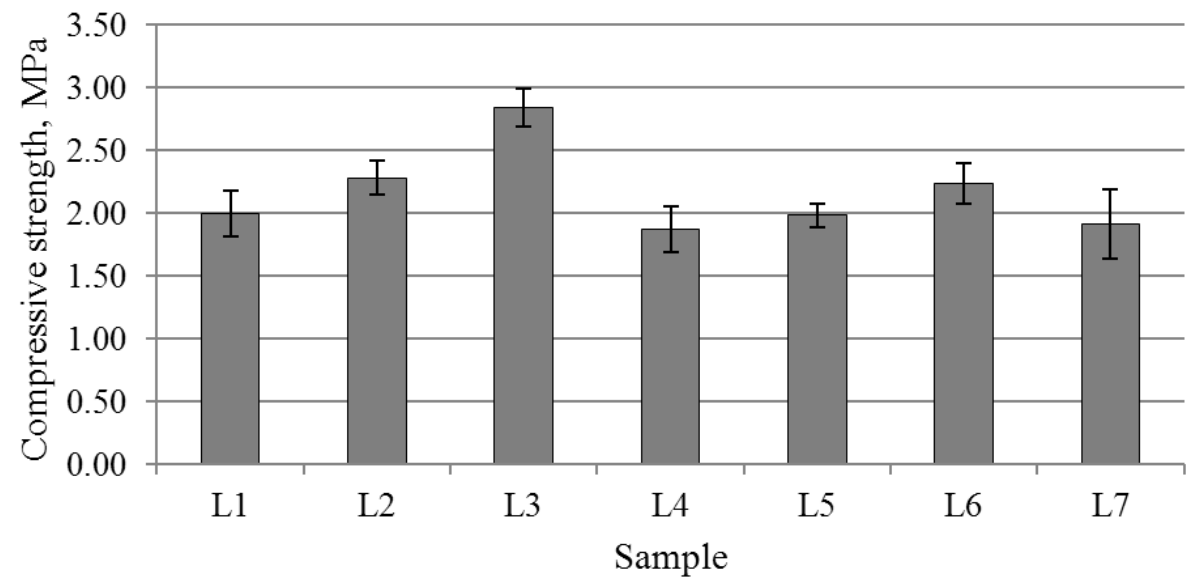

Fig. 4. Compressive strength of wood-geopolymer

By means of composition L6 and L7 are equal (see Table 1), however, different is the heating and pressing time. Mechanical properties of wood-geopolymer are not only affected by the composition, but also the technology of preparation. In this case, the sample L6 was stored in elevated temperature for longer. Palamo [13] points out that not only the composition but also the hardening and heating time affects the mechanical properties of geopolymer. Looking at the L5 sample, it is clear that, although the modulus of elasticity and at the same time bending strength is very high, the compressive strength is relatively low. In this case, it is probable that when the water dries, it creates empty pores that retain the high elasticity of the material, but the geopolymer does not obtain sufficient strength. While the sodium silicate provides the best characteristics of strength, just losing a bit in elasticity, as dry sodium silicate is brittle.

Looking at the density influence on the compressive strength, it can be seen that the increase in density also increases the compressive strength (Figure 5). Correlation coefficient $r=0.82$ (coefficient of determination $\mathrm{R}^{2}=0.676$ ), suggesting a direct effect of density on the compression strength.

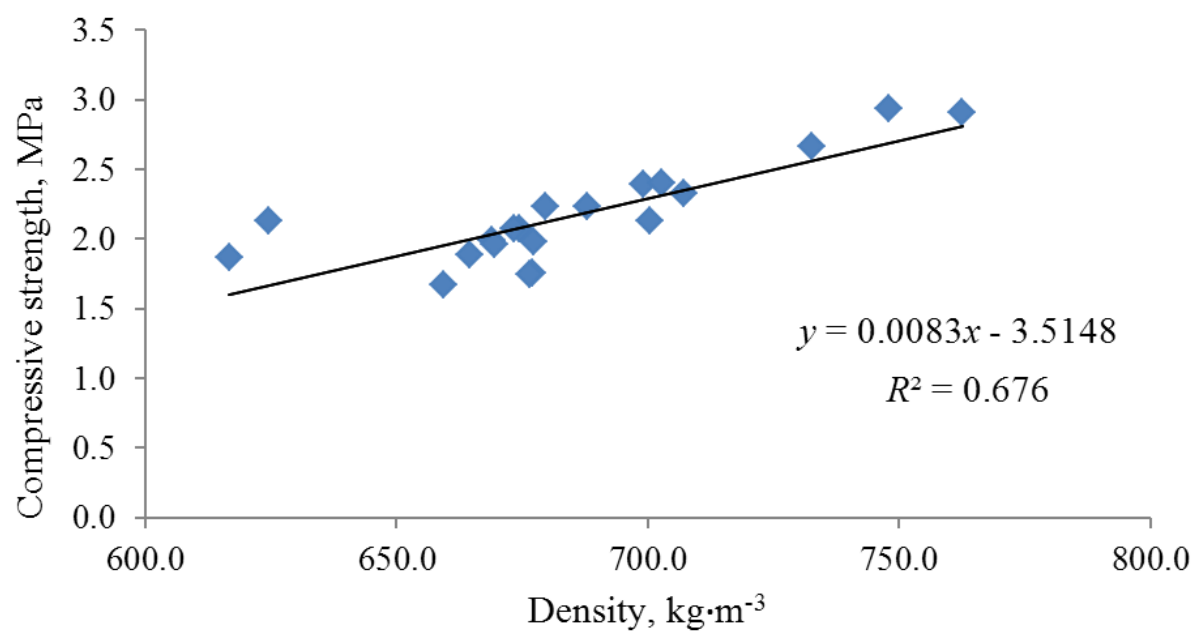

Fig. 5. Compressive strength dependence on the density

Comparing the obtained data with the inorganic cement-related wood particle composites, the picture is similar. Depending on the material density, mechanical characteristics are as follows: the bending strength in the range of 1.7 to $5.5 \mathrm{MPa}$, modulus of elasticity ranges from 621 to $1241 \mathrm{MPa}$ and the compressive strength in the range of 0.69 to $5.5 \mathrm{MPa}$ (increased density increases strength) [1]. Tested wood-geopolymer composites are close to these averages. 
It is clear that both the composition and preparation technology influence wood-geopolymer properties, but additional studies are required in order to get higher predictability of results.

Wood-geopolymer swelling: not observed pronounced differences between the swelling in width and length. Wood-geopolymer swelling in length and width ranges between 2 and $3 \%$. Woodgeopolymer swelling in thickness ranges between 4 and $12 \%$. The best shape stability was recorded for sample L6 having length swelling on average $2.28 \%$, width swelling $2.21 \%$ and thickness swelling $4.02 \%$. During soaking there was observed no sample dissolution or decomposition, however after removing the samples, the water was discolored and became more alkaline, which indicates the presence of sodium silicate and its partial leaching from the samples.

Wood-geopolymer and geopolymer thermal conductivity: the average wood-geopolymer thermal conductivity is about three times lower than the geopolymer, respectively $0.095 \pm 0.007 \mathrm{~W} \cdot \mathrm{m}^{-1} \cdot \mathrm{K}^{-1}$ and $0.310 \pm 0.061 \mathrm{~W} \cdot \mathrm{m}^{-1} \cdot \mathrm{K}^{-1}$.

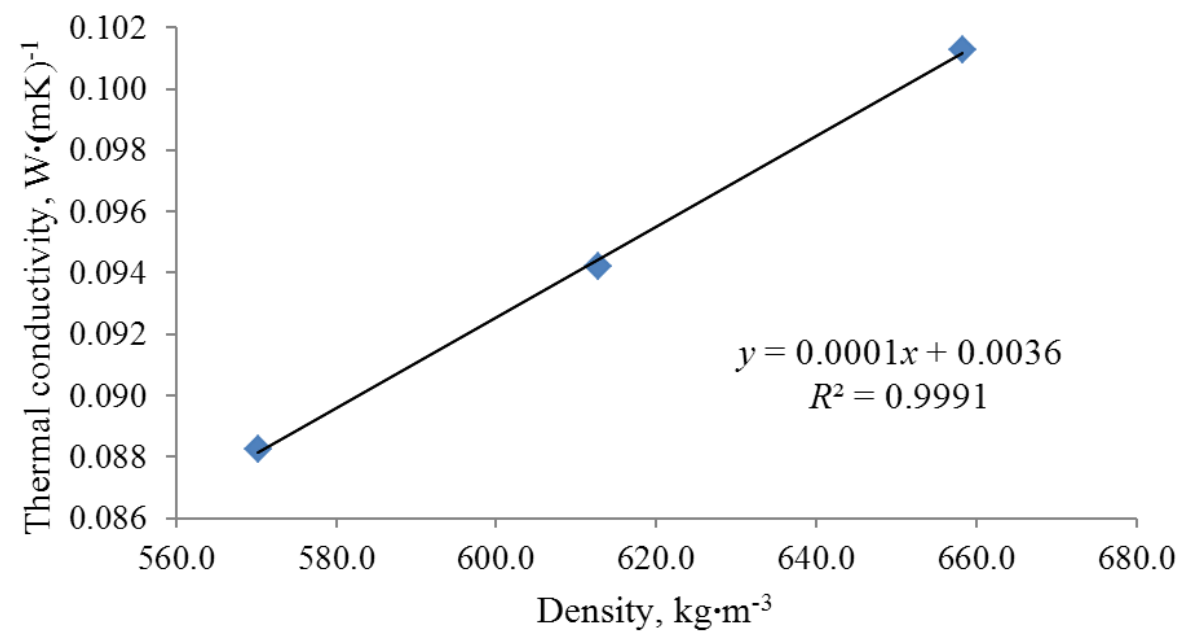

Fig. 6. Thermal conductivity dependence on the density

There is observed a tendency that wood-geopolymer thermal conductivity is directly dependent on the density (Figure 6). It can be concluded that the thermal conductivity can be reduced by reducing the density, or on the contrary, increased by increasing the density of the composite.

\section{Conclusions}

1. Wood-geopolymer composite density correlates with the compressive strength and thermal conductivity. Depending on the composition, wood-geopolymer shows $1.5 \mathrm{MPa}$ of bending strength, $2.84 \mathrm{MPa}$ - compression strength, material swelling in range of $4 \%$ and the lowest thermal conductivity $-0.088 \mathrm{~W} \cdot(\mathrm{mK})^{-1}$.

2. Wood chips preferably should be sprayed with a geopolymer during mixing them in order to reduce adhesive substance consumption and ensure a smooth particle deposition.

3. Reduced clay fraction particle size could improve the dissolution of clay in alkali and reduce the required amount of binder.

\section{Acknowledgements}

The authors express their thanks to National Research Programme Forest and Earth Entrails Resources: Research and Sustainable Utilization - New Products and Technologies (ResProd) 2014.-2017 for financial support.

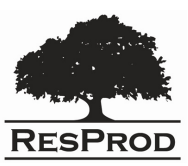

\section{References}

1. Wood handbook: wood as an engineering material. Edited by Vick B. Madison: Forest Products Laboratory. 1999, 463 p.

2. Maloney T.M. The Family of Wood Composite Materials. Forest products journal, Vol. 46. No. 2, 1996, pp. 19-24. 
3. Meng Q.K., Hetzer M., De Kee D. PLA/clay/wood nanocomposites: nanoclay effects on mechanical and thermal properties. Journal of Composite Materials, Vol. 45, 2011, pp. 1145-1158.

4. Sarmin S. N., Welling J., Krause A. Investigating the possibility of geopolymer to produce inorganic-bonded wood for multifunctional construction material - a review. Biorecurces, Vol. 9(4), 2014, pp. 7941-7950.

5. Alomayri T., Low I.M. Synthesis and characterization of mechanical properties in cotton fiberreinforced geopolymer composites. Journal of Asian Ceramic Societies, Vol. 1, 2013, pp. 30-34.

6. Davidovits J. Geopolymer Chemistry and Applications. 4th edition. Quentin France, Galilée: Institut Géopolymère. 2015, 37 p.

7. Morozovs A., Bukšāns E., Spulle U., Tuherm H. Sustainable Use of Local Resources (Entrails of the Earth, Foreomposites forEnhancement of Construction`s Reaction to Fire. Riga: Latvian State Institute of Wood Chemistry, 2013, pp. 107-110.

8. Ryu G.S., Lee Y.B., Koh K.T., Chung Y.S. The mechanical properties of fly ash-based geopolymer concrete with alkaline activators. Construction and Building Materials, Vol. 47, 2013, pp. 409-418.

9. Gouny F., Fouchal F., Maillard P., Rossignol S. Study of the Effect of Siliceous Species in the Formation of a Geopolymer Binder: Understanding the Reaction mechanisms among the Binder, Wood, and Earth Brick. Industrial \& Engineering Chemistry Research, Vol. 53, 2014, pp. 3559-3569.

10. Sarmin S.N. Study on Properties of Lightweight Cementitous Wood Compozite Containing Fly Ash / Metakaolin. Pro Lingo, Vol. 11(4), 2015, pp. 116-121.

11. Shaikh F. U. A Review of mechanical properties of short fibre reinforced geopolymer composites. Construction and Building Materials, Vol. 43, 2013, pp. 37-49.

12. Sarmin S. N. Lightweight Building Materials of Geopolymer Reinforced Wood Particles Aggregate - A Review. Applied Mechanics and Materials, Vol. 802, 2015, pp. 220-224

13. Palomo A., Grutzeck M.W., Blanco M.T. Alkali-activated fly ashes A cement for the future. Cement and Concrete Research, Vol. 29, 1999, pp. 1323-1329.

14. Xu H., van Deventer J.S.J. Geopolymerisation of multiple minerāls. Minerals Engineering, Vol. 15, 2002, pp. 1131-1139.

15. Sperberga I, Sedmale G., Cimmers A. Chemical and Thermal Treatment of Raw Materials and their Role in the Product Development. Scientific Journal of Riga Technical University, Vol. 24, 2011, pp. 30-34.

16. Zuhua Z., Xiao Y., Huajun Z., Yue C. Role of water in the synthesis of calcined kaolin-based geopolymer. Applied Clay Science, Vol. 43, 2009, pp. 218-223.

17. Diop M. B., Michael E., Grutzeck W. Sodium silicate activated clay brick. Bulletin of Engineering Geology and the Environment, Vol. 67, 2008, pp. 499-505.

18. LVS EN 310:2001 standard "Wood-based panels; determination of modulus of elasticity in bending and of bending strength" 